\title{
PENGARUH HARGA DAN MUTU TERHADAP KEPUTUSAN PEMBELIAN KARTU SELULER
}

\author{
Fitrianingrum \\ Tries Edy Wahyono
}

\begin{abstract}
Abstrak: Perusahaan provider saat ini semakin banyak dan memiliki strategi bersaing yang berbeda-beda untuk itu setiap perusahaan perlu memiliki suatu pemasaran yang jitu dalam memasarkan produknya, salah satu bentuk pemasaran yang mampu mendukung dalam memasarkan produk kartu seluler adalah penggunaan strategi atribut produk yang meliputi harga dan mutu. Penelitian ini bertujuan untuk mengetahui: 1). Adakah hubungan atribut produk harga dengan keputusan pembelian kartu perdana? 2). Adakah hubungan atribut produk mutu dengan keputusan pembelian kartu perdana? 3). Adakah hubungan atribut produk harga dan mutu dengan keputusan pembelian secara bersama-sama?. Jenis penelitian ini adalah penelitian explanatory research guna menjelaskan hubungan kausal antara variabel-variabel melalui pengujian hipotesis. Populasi dalam penelitian ini adalah 355 responden. Metode yang digunakan adalah regresi linier berganda. Hasil penelitian menunjukan bahwa variabel harga dan mutu secara bersama berpengaruh signifikan terhadap keputusan pembelian kartu seluler. Pada uji t semua variabel berpengaruh secara signifikan terhadap keputusan pembelian dengan variabel harga memiliki nilai 0,044 , sedangkan mutu memiliki nilai sebesar $0,000<0,05$.
\end{abstract}

Kata Kunci: Atribut Produk, Keputusan Pembelian

\section{PENDAHULUAN}

Di dalam kehidupan yang semakin modern ini, dimana tingkat persaingan semakin ketat dalam ilmu pengetahuan, teknologi, maupun informasi, maka masalah yang dihadapi dunia usaha semakin rumit. Perkembangan ekonomi serta dukungan sarana transportasi yang cukup banyak, berdampak secara langsung terhadap mobilitas manusia itu sendiri. Sarana transportasi yang disediakan baik di dalam maupun di luar kota akan membuat jarak dan waktu semakin tak berarti, terbukti hanya dalam waktu beberapa jam saja seseorang dapat berpindah dari satu tempat ke tempat lain dengan jarak ratusan bahkan ribuan mil. Untuk menjembatani komunikasi orang-orang yang berlainan tempat itu dibutuhkan teknologi telekomunikasi sehingga muncul telepon seluler (ponsel), sehingga orang

Fitrianingrum, Alumni Prodi Manajemen Fakultas Ekonomi Universitas Kanjuruhan Malang

Tries Edy Wahyono, Dosen Prodi Manajemen Fakultas Ekonomi Universitas Kanjuruhan Malang 
dapat menghubungi dan dihubungi dimanapun berada dengan jaringan yang tersedia.

Telepon seluler adalah suatu jenis telepon bergerak tanpa kabel yang menggunakan teknologi sel sebagai akses komunikasinya. Pada masa kini ponsel sudah bukan merupakan barang mewah lagi dibanding beberapa tahun silam. Masyarakat sudah banyak memanfaatkan teknologi ini baik bagi mereka yang mempunyai aktifitas yang menuntut mobilitas tinggi maupun mereka yang hanya sekedar mengikuti trend. Begitu populernya telepon seluler ini sehingga mengakibatkan permintaan kartu seluler yang cukup tinggi dan ikut mendorong pertumbuhan populasi ponsel di Indonesia. Persaingan diantara penyedia layanan atau operator telepon seluler menjadi tidak terelakkan. Setiap operator berlombalomba dalam hal teknologi dan pelayanan produknya untuk menarik pelanggan.

Salah satu yang banyak bermunculan dari industri seperti disebutkan di atas adalah produsen kartu seluler (perdana), yang merupakan salah satu dari produk jasa. Kartu seluler sudah dikenal oleh masyarakat Indonesia sejak lama sebagai alat komunikasi yang hanya dapat digunakan pada ponsel/handphone. Beberapa merek kartu seluler telah dikenal oleh masyarakat seperti KartuHALO, KartuAs, simPATI yang dikeluarkan oleh PT. Telkomsel Tbk. Jumlah pelanggan data PT Telekomunikasi Selular (Telkomsel) terus meningkat, hingga menembus 40 juta user dalam hitungan tiga bulan terakhir terjadi peningkatan jumlah pelanggan mencapai 60 persen dari 82 juta pelanggan atau sekitar 50 persen dari jumlah pengguna layanan selular di Indonesia. Republika.co.id, Jakarta, (2011).

Sedangkan PT. Excelkomindo Pratama yang mengeluarkan produk Jempol dan Bebas mampu menembus jumlah pelanggan hingga 40 juta user. Untuk PT. Indosat Tbk dengan produknya Mentari, IM3 membukukan jumlah pelanggannya sebesar 37,8 juta pelanggan. Republika.co.id, Jakarta, (2011). Dengan adanya berbagai merek kartu seluler, maka berdampak pula pada ketatnya persaingan untuk mendapatkan konsumen.

Aktivitas kompetitif yang dilakukan oleh perusahaan biasanya adalah menetapkan harga secara agresif untuk membatasi persaingan dengan menurunkan harga yang bertujuan untuk meningkatkan daya tarik produk. Kondisi ini jelas menimbulkan perang harga yang sebenarnya cenderung merugikan dalam jangka panjang, hal ini akan merugikan perusahaan karena perusahaan secara otomatis akan kehilangan konsumen tetapnya, konsumen akan beranggapan bahwa dengan harga yang murah belum tentu mutu kartu tersebut baik. Kompetisi dengan peranan sentral adalah harga, ternyata tidak menguntungkan perusahaan dalam jangka panjang, maka semakin pentingnya perusahaan untuk mengembangkan keunggulan kompetitif berkelanjutan berlandaskan pada kompetisi non harga.

Banyak perusahaan yang ingin mengambil hati konsumen, berbagai cara pun dilakukan oleh perusahaan antara lain dengan memainkan harga, meningkatkan mutu, dan menambah layanan dengan menawarkan berbagai paket misalnya paket telepon murah, paket SMS, paket internet dan sebagainya. Perusahaan harus pintar-pintar membaca peluang yang dianggap mampu menaikkan tingkat penjualan dan menarik perhatian konsumen sehingga mampu membuat konsumen untuk membeli produk yang ditawarkan.

Setiap perusahaan harus berupaya menghasilkan dan menyampaikan barang dan jasa yang diinginkan konsumen dengan harga yang pantas, dengan demikian setiap 
perusahaan harus mampu memahami perilaku konsumen pada pasar sasarannya, karena kelangsungan hidup perusahaan tersebut sebagai organisasi yang berusaha memenuhi kebutuhan dan keinginan para konsumen sangat tergantung pada perilaku konsumennya. Melalui pemahaman perilaku konsumen, pihak manajemen perusahaan dapat menyusun strategi dan program yang tepat dalam rangka memanfaatkan peluan yang ada dan mengungguli para pesaingnya.

Para pemasar sadar bahwa keputusan pembelian terhadap suatu produk kartu perdana merupakan suatu ukuran keterkaitan seorang konsumen pada sebuah produk dan juga mencerminkan suatu pengaruh dari fungsi psikologis terhadap pengambilan keputusan dan evaluasi pembelian seorang konsumen. Pemasar harus selalu memperhatikan tingkat harga, mutu, merek serta fasilitas/layanan yang diberikan kepada konsumen guna memperkuat penjualan kartu prabayar.

Seorang konsumen akan melihat sesuatu produk berdasarkan karakteristik atau ciri atau atribut dari produk tersebut (Sumarwan, 2003). Atribut produk merupakan bagian yang tak terpisahkan dari strategi produk yang dapat dikontrol langsung oleh perusahaan sebagai suatu rangsangan yang diperhatikan dan dievaluasi oleh konsumen dalam proses keputusan pembelian. Melalui atribut produk itulah, suatu produk dipandang berbeda oleh konsumen dari produk pesaingnya. Atribut produk ini sangat mempengaruhi reaksi konsumen memutuskan untuk membeli suatu produk karena terpengaruh atribut produk dan atribut produk yang bernilai lainnya.

Menurut Engel dalam Tjiptono (2008) Perilaku konsumen sendiri merupakan tindakan-tindakan individu yang secara langsung terlibat dalam usaha memperoleh, menggunakan, dan menetukan produk dan jasa, termasuk proses pengambilan keputusan yang mendahului dan mengikuti tindakan-tindakan tersebut. Dari pengertian ini dapat diketahui bahwa pemahaman terhadap perilaku konsumen tidak mudah, tetapi cukup sulit dan kompleks, hal ini disebabkan oleh banyaknya variabel yang mempengaruhi dan variabel-variabel tersebut cenderung saling berinteraksi. Meskipun demikian, bila hal tersebut dapat dilakukan, maka perusahaan yang bersangkutan akan dapat meraih keuntungan jauh lebih besar daripada para pesaingnya, karena dengan dipahaminya perilaku konsumennya, perusahaan dapat memberikan kepuasan secara lebih baik kepada konsumennya (Kotler, 2008).

Setiap mengambil keputusan untuk membeli suatu produk, konsumen akan mencari informasi-informasi mengenai barang/produk/jasa untuk mendapatkan barang yang sesuai dengan kebutuhan dan keinginan mereka. Dengan melihat atribut suatu produk yang akan mereka beli akan menentukan produk apa yang sesuai dengan keinginan mereka, namun tidak semua dari atribut produk dapat memenuhi kebutuhan dan keinginan konsumen.

Penelitian ini dilakukan di Universitas Kanjuruhan Malang dengan objek penelitiannya adalah mahasiswa pengguna kartu seluler dari produk Telkomsel, Indosat dan XL. Hal ini dilakukan karena mahasiswa sering mengganti kartu mereka dengan alasan yang bermacam-macam dan faktor apa saja yang mempengaruhi mereka dalam mengambil keputusan dalam membeli kartu perdana yang mereka gunakan. Peneliti menyadari bahwa hal ini masih relevan dan cukup representative, sehingga dari uraian diatas dipandang perlu untuk mengadakan penelitian untuk mengetahui sejauh mana variabel-variabel atribut produk dari 
kartu perdana berpengaruh terhadap keputusan pembelian konsumen di Universitas Kanjuruhan Malang. (1) Adakah hubungan atribut produk harga dengan keputusan pembelian kartu perdana?. (2) Adakah hubungan atribut produk mutu dengan keputusan pembelian kartu perdana?. (3) Adakah hubungan atribut produk harga dan mutu dengan keputusan pembelian secara bersama-sama?

\section{TINJAUAN PUSTAKA} Keputusan Pembelian

Perilaku Konsumen adalah perilaku yang ditunjukkan konsumen dalam pencarian akan pembelian, penggunaan, pengevaluasian, dan penggantian produk dan jasa yang diharapkan dapat memuaskan kebutuhan konsumen Schiffman dan Kanuk (2004). Perilaku konsumen menyangkut masalah keputusan yang diambil seseorang dalam persaingannya dan penentuan untuk mendapatkan dan mempergunakan barang dan jasa. Secara khusus, pemasar harus mengidentifikasi orang yang membuat keputusan pembelian, jenis keputusan pembelian, dan langkah-langkah dalam proses pembelian.

Produsen jasa dapat menonjolkan atribut-atribut yang memberi pengaruh signifikan kepada keputusan pembelian (ulang) konsumen. Atribut-atribut jasa yang bisa ditonjolkan kepada konsumen menurut Yazid (2005) mencakup:

a. Kualitas pencarian (search quality), yaitu atribut yang dapat ditentukan konsumen sebelum membeli suatu barang. Termasuk dalam kualitas pencarian warna, gaya, harga, perasaan, kecocokan, kekerasan dan bau.

b. Kualitas pengalaman (experience quality), yaitu atribut yang dapat diketahui setelah pembelian dilakukan atau selama proses konsumsi berlangsung. Termasuk dalam kualitas ini adalah selera dan dapat tidaknya barang itu dipakai.

c. Kualitas keyakinan (credence quality), yaitu karakteristik yang mungkin sulit bagi konsumen untuk mengevaluasinya meskipun mereka telah membeli maupun telah mengkonsumsinya.

Menurut Swasta dan Handoko (2000) proses pengambilan keputusan melalui lima tahap yaitu :

1. Menganalisis atau pengenalan kebutuhan dan keinginan.

Dalam penganalisaan kebutuhan dan keinginan suatu proses ditujukan untuk mengetahui adanya kebutuhan dan keinginan yang belum terpenuhi. Jika suatu kebutuhan diketahui, maka konsumen akan memahami adanya kebutuhan yang segera dipenuhi atau masih ditunda pemenuhannya. Tahap ini adalah proses pembelian mulai dilakukan.

2. Pencarian informasi dan penilaian sumber-sumber.

Pencarian informasi dapat bersifat aktif atau pasif, internal atau eksternal, pencarian informasi yang bersifat aktif dapat berupa kunjungan terhadap beberapa toko untuk membuat perbandingan harga dan kualitas produk, sedangkan pencarian informasi pasif hanya dengan membaca iklan di majalah atau surat kabar tanpa mempunyai tujuan khusus tentang gambaran produk yang diinginkan.

Pencarian informasi internal tentang sumber-sumber pembelian dapat berasal dari komunikasi perorangan dan pengaruh perorangan 
yang terutama berasal dari komunikasi perorangan dan pengaruh perorangan yang terutama berasal dari pelopor opini, sedangkan informasi eksternal berasal dari media masa dan sumber informasi dari kegiatan pemasaran perusahaan.

3. Penilaian dan seleksi terhadap alternatif pembelian.

Meliputi dua tahap yaitu menetapkan tujuan pembelian dan menilai serta mengadakan seleksi terhadap alternatif pembelian berdasarkan tujuan pembelian. Tujuan pembelian bagi masing-masing konsumen tidak selalu sama, tergantung pada jenis produk dan kebutuhannya.

4. Keputusan untuk membeli.

Tahapan dalam proses pengambilan keputusan pembelian dimana konsumen benar-benar membeli produk. Keputusan untuk membeli atau tidak produk yang ditawarkan. Keputusan untuk membeli yang diambil oleh pembeli sebenarnya merupakan kesimpulan dari sejumlah keputusan, misalnya: keputusan tentang jenis produk, bentuk produk, jumlah produk dan sebagainya. Apabila produk yang dihasilkan perusahaan sesuai dengan apa yang diharapkan konsumen untuk memuaskan kebutuhan dan keinginan, maka produk tersebut mampu menarik minat untuk membeli. Bila konsumen dapat dipuaskan maka pembelian berikutnya akan membeli merk tersebut lagi dan lagi.

5. Perilaku sesudah pembelian.

Setelah melakukan pembelian produk, konsumen akan mengalami suatu tingkat kepuasan atau ketidakpuasan. Konsumen akan melakukan tindakan setelah kegiatan membeli dalam hal penggunaan produk tersebut sehingga harus diperhatikan oleh pemasar bahwa tugas pemasaran tidak berakhir ketika produk sudah dibeli tetapi terus sampai pada periode setelah pembelian.

Faktor-Faktor Yang Mempengaruhi Keputusan Pembelian

Kotler (2005) mengemukakan bahwa faktor-faktor yang mempengaruhi perilaku pembelian konsumen, seperti yang disajikan pada gambar dibawah.

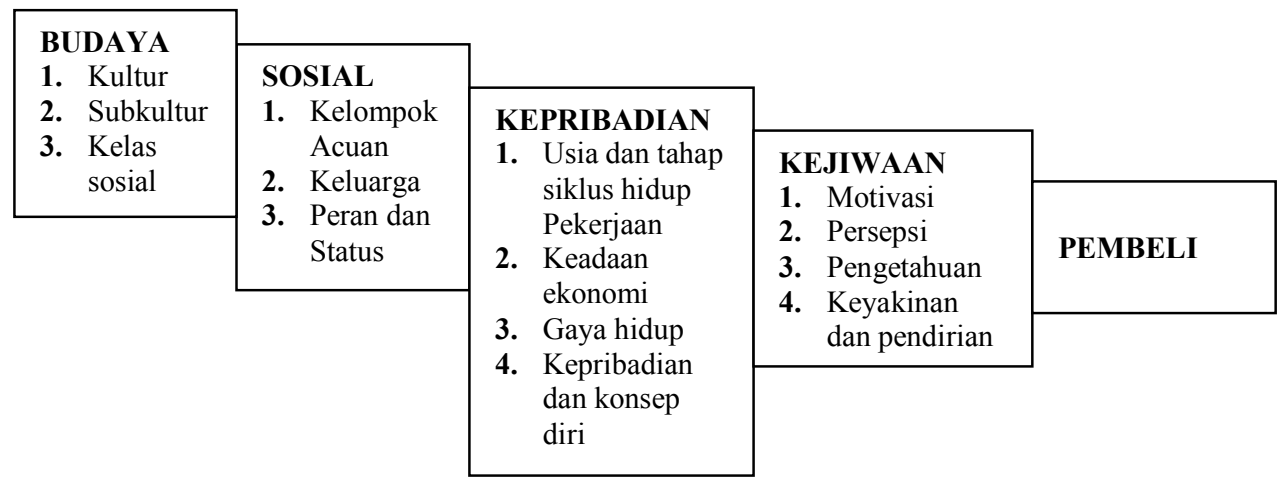

Gambar 1: Faktor - Faktor yang Mempengaruhi Perilaku Pembelian

Sumber: Kotler, 2005 


\section{Tahap-Tahap dalam Proses Keputusan Pembelian}

Konsumen banyak mengambil keputusan setiap hari. Kebanyakan perusahaan besar meneliti pengambilan keputussan konsumen secara sangat rinci. Mereka ingin mencari jawaban atas pertanyaan tentang apa yang dibeli konsumen, apa yang mereka beli, dan mengapa mereka membeli. Para konsumen melewati lima tahap dalam memutuskan pembelian seperti dalam gambar di bawah ini:

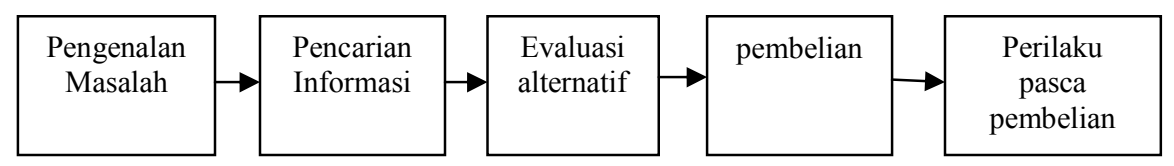

Gambar 2 : Tahapan Proses Pembelian

Sumber : Kotler, 2005

Model gambar diatas menunjukkan bahwa para konsumen harus melalui seluruh lima urutan tahapan ketika membeli produk, namun tidak selalu begitu. Para konsumen dapat melewati atau membalik beberapa tahap tergantung produk apa yang akan mereka beli. Namun dalam gambar 2.2 akan digunakan apabila konsumen menghadapi pembelian baru dengan keterlibatan yang tinggi (Kotler, 2005).

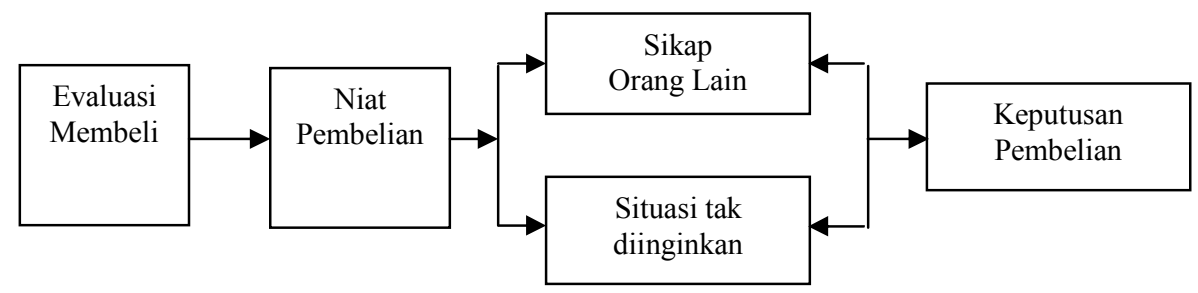

Gambar 3 : Langkah-Langkah Antara Evaluasi Alternatif dan Keputusan Pembelian

Sumber : Kotler, 2005

\section{Atribut Produk}

Pengertian atribut produk dalam perilaku konsumen dibagi menjadi dua pengertian. Dalam arti sempit, atribut adalah keseluruhan karakteristik yang melekat pada produk tersebut. Sedangkan dalam artii luas, atribut merupakan keseluruhan faktor yang di pertimbangkan konsumen untuk membeli suatu produk/barang. Atribut produk adalah unsur-unsur produk yang dipandang penting oleh konsumen dan dijadikan dasar pengambilan keputusan pembelian. (Tjiptono, 2002)

Menurut Gitosudarmo (2000) atribut produk adalah suatu komponen yang merupakan sifat-sifat produk yang menjamin agar produk tersebut dapat memenuhi kebutuhan dan keinginan yang diharapkan pembeli. Adanya atribut yang melekat pada suatu produk dapat digunakan konsumen untuk menilai dan mengukur kesesuaian atribut produk dengan kebutuhan dan keinginan. Bagi perusahaan dengan mengetahui atribut-atribut apa saja yang bisa mempengaruhi keputusan 
pembelian maka dapat ditentukan strategi untuk mengembangkan dan menyempurnakan produk agar lebih memuaskan konsumen.

Atribut suatu produk dapat meliputi berbagai macam sifat atau cirri termasuk antara lain bentuk atau desain produk, warna, bungkus, merek, label, prestise perusahaan, pelayanan perusahaan dan sebagainya yang diberikan penjual kepada pembeli untuk memberikan kepuasan terhadap kebutuhan serta keinginannya.

Atribut-atribut suatu produk disamping yang tercermin dalam produknya sendiri seperti bentuknya, daya tahannya, warna, aroma, terdapat pula atribut yang terdiri dari kemasan, merek, gambar logo atau trade marknya maupun labelnya. Dari atribut itulah suatu produk akan dipandang oleh konsumen berbeda dengan produk yang dikeluarkan oleh pesaingnya. Setiap produk akan memiliki atribut yang berbeda dengan jenis produk yang lain.

Pengembangan produk dan jasa memerlukan pendefinisian manfaatmanfaat yang akan ditawarkan. Manfaat-manfaat tersebut kemudian dikomunikasikan dan disampaikan melalui atribut-atribut produk seperti kualitas, fitur, serta gaya dan desain (Kotler \& Armstrong, 2003). Menurut Gitosudarmo (2000) atribut produk dapat dibedakan menjadi dua macam yaitu: atribut yang bersifat teknis dan atribut yang bersifat nonteknis. Atribut produk yang bersifat teknis tercermin pada produk itu atau yang merupakan inti dari produk (core produk). Sedangkan atribut nonteknis dapat ditampilkan dalam beberapa macam bentuk antara lain desain produk, bungkus, atau kemasan produk, merek label. Namun tidak semua atribut diatas dijadikan dasar penelitian, peneliti hanya memfokuskan pada atribut harga dan mutu. Atribut tersebut dianggap penting dan perlu diperhatikan oleh produsen atau perusahaan provider.

\section{Hubungan Antara Atribut Produk Terhadap Keputusan Pembelian}

Atribut produk merupakan bagian tak terpisahkan dari strategi produk yang dapat dikontrol langsung dari perusahaan, sebagai suatu rangsangan yang diperhatikan dan dievaluasi oleh konsumen dalam proses keputusan pembelian. Dari atribut-atribut produk itulah suatu produk dipandang berbeda oleh konsumen dari produk pesaingnya.

Atribut produk ini sangat mempengaruhi reaksi konsumen terhadap produk yang ditawarkan. Tidak jarang konsumen memutuskan untuk membeli karena terpengaruh oleh harga, merek, mutu, fasilitas maupun atribut bernilai lainnya.

Atribut disini didefinisikan sebagai unsur-unsur yang dipandang penting oleh konsumen dan dijadikan dasar pengambilan keputusan pembelian (Tjiptono, 2001). Sedangkan dalam proses pengambilan keputusan pembelian konsumen biasanya akan melewati beberapa tahapan-tahapan tertentu. Tahapan-tahapan dalam proses keputusan tersebut meliputi pengenalan masalah/kebutuhan, pencarian informasi, evaluasi alternatif, keputusan membeli dan perilaku pasca pembelian.

Karena keterbatasan daya pikir konsumen yang pada umumnya hanya mampu mempertimbangkan 2-5 atribut saja, maka pemasar harus bisa mengetahui atribut produk yang menjadi pertimbangan konsumen dalam proses keputusan pembeliannya. Dengan demikian, perusahaan dapat membuat kombinasi atribut produk yang sesuai dengan kebutuhan dan keinginan konsumen sasaran, 
pengetahuan tersebut dapat dijadikan sebagai dasar untuk memperbaiki kekurangan yang ada pada produk yang telah ada.

\section{Kerangka Konseptual Penelitian}

Produk pada intinya merupakan segala sesuatu yang dapat ditawarkan kepada pasar untuk diperhatikan, dimiliki, digunakan atau dikonsumsi yang dapat memuaskan keinginan atau kebutuhan pemakainya (Kotler \& Armstrong, 2003). Produk yang berhasil merupakan produk yang dapat memnuhi kebutuhan dan keinginan konsumennya. Keberhasilan itu akan sangat ditentukan oleh sifat-sifat yang terkandung dalam produk tersebut seperti komponen-komponen yang membentuk apa yang disebut atribut produk.

Atribut produk adalah suatu komponen yang merupakan sifat-sifat produk yang menjamin agar produk tersebut dapat memnuhi kebutuhan dan keinginan yang diharapkan oleh pembeli (Gitosudarmo, 2000). Atribut disini didefinisikan sebagai unsur-unsur yang dipandang penting oleh konsumen dan dijadikan dasar pengambilan keputusan pembelian (Tjiptono, 2002). Hubungan atribut produk terhadap keputusan pembelian dapat dijelaskan dengan berbagai variabel atribut produk yang dapat mempengaruhi konsumen dalam memutuskan pembelian.

Menurut Tjiptono (2002) harga memiliki peranan utama dalam proses pengambilan keputusan para pembeli, yaitu peranan alokasi dan peranan informasi. Peranan alokasi dari harga, yaitu fungsi harga dalam membantu para pembeli untuk memutuskan cara memperoleh manfaat utilitas tertinggi yang diharapkan berdasarkan daya belinya. Peranan informasi dari harga, yaitu fungsi harga dalam mendidik konsumen mengenai faktor-faktor produk, seperti kualitas.

Mutu adalah salah satu alat penting bagi pemasar untuk menetapkan posisi. Mutu produk berartikemampuan produk untuk melaksanakan fungsinya, termasuk didalamnya keawetan, keandalan, ketepatan, kemudahan dipergunakan dan diperbaiki, serta atribut bernilai yang lain (Kotler dan Armstrong, 2003).

Kepiawaian konsumen dalam memutuskan pembelian produk sesuai dengan kebutuhan yang semakin meningkat. Kotler dan Armstrong (2001) menyatakan bahwa sesuai dengan konsep produk, konsumen akan menyatakan bahwa sesuai dengan konsep produk yang menawarkan mutu terbaik, kinerja terbaik, dan sifat terbaik dan bahwa organisasi harus mencurahkan perbaikan produk secara terus menerus.

Fenomena yang terjadi saat ini pada pengguna kartu selular adalah sering pindah atau ganti-ganti kartu. Hal ini dimungkinkan karena Makin murahnya harga kartu perdana dicurigai sebagai salah satu pemicu tingginya tingkat pelanggan kartu selular. Ada kecenderungan pelanggan baru memberi kartu perdana dan hanya memanfaatkan kartu itu sampai pulsa habis saja. Dengan harga kartu perdana Rp 5 ribu, orang bisa mendapatkan pulsa hingga Rp 15 ribu. Karena itu, daripada membeli pulsa, lebih baik membeli kartu perdana. Ini yang menyebabkan churn rate tinggi. Dari sini dapat disimpulkan bahwa murahnya harga kartu perdana disebabkan oleh kelebihan pasokan kartu perdana.

Sumber-sumber lain mengungkapkan bahwa churnrate juga disokong oleh kurang menariknya layanan operator, banyaknya pelanggan yang pindah ke operator tertentu agar bisa telepon atau SMS gratis ke rekan bicara sesama operator, alasan tariff mahal dan pengguna nomor untuk keperluan sekali pakai. 
Konsumen dalam hal ini dihadapkan pada banyak pilihan produk dengan atribut-atributnya sehingga untuk mendapatkan produk yang sesuai dengan kebutuhannya mereka harus mengenali kebutuhannya dulu baru mengambil keputusan pembelian. Pengambilan keputusan konsumen tidak bisa dilakukan begitu saja. Agar produk yang diharapkan sesuai dengan kebutuhannya, mereka dapat mengambil keputusan pembelian melalui proses keputusan pembelian konsumen yang mencakup tentang: kebutuhan konsumen, pengenalan masalah, pencarian informasi, evaluasi alternatif, dan keputusan pembelian (Kotler, 2005).

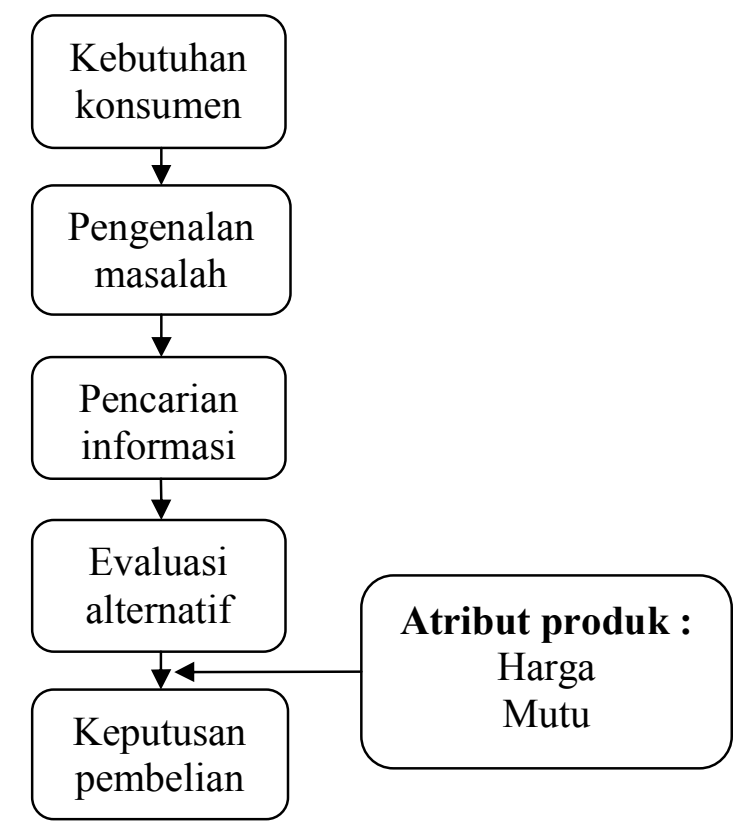

Gambar 4 : Kerangka Pikir Penelitian

Metode penelitian yang digunakan dalam suatu penelitian biasanya akan menentukan desain penelitian yang dipilih. Metode penelitian berkaitan dengan prosedur yang memberikan urut-urutan pekerjaan yang harus dilakukan seorang peneliti dalam melakukan penelitian, serta instrumen penelitian yang digunakan. Desain penelitian sangat penting artinya bagi suatu penelitian karena desain ini akan memberikan prosedur yang sistematis dalam melakukan penelitian.

Penelitian ini termasuk penelitian sebab-akibat yaitu penelitian yang menunjukkan dua keadaan, dimana antara keadaan pertama dengan yang kedua terdapat hubungan sebab-akibat. Keadaan pertama diperkirakan menjadi penyebab keadaan kedua, sedangkan keadaan pertama berpengaruh terhadap keadaan kedua (Arikunto, 2002).

Peneliti dalam penelitian ini menggunakan variabel atribut produk berdasarkan dari berbagai teori maupun referensi-referensi dari berbagai sumber. Survei penelitian ini adalah kalangan mahasiswa pengguna kartu seluler (simcard), untuk itu variabel yang digunakan dari penelitian ini hanya mengambil beberapa variabel atribut yang sudah pernah diteliti oleh peneliti terdahulu maupun yang 
ditulis dalam berbagai sumber referensi. Variabel atribut produk yang digunakan dalam penelitian ini meliputi harga dan mutu. Peneliti beranggapan variabel ini dianggap yang sering menjadi pertimbangan mahasiswa untuk membeli kartu seluler (simcard).

Berdasarkan penjelasan diatas, maka secara umum tujuan penelitian ini adalah untuk mengetahui pengaruh atribut produk terhadap keputusan pembelian konsumen (mahasiswa) dalam membeli kartu seluler. Dari tujuan tersebut, variabel bebas dalam penelitian ini adalah atribut produk (X) yang terdiri dari harga (X1), mutu (X2). Sedangkan variabel terikatnya adalah proses keputusan pembelian konsumen dalam membeli kartu seluler (Y).

Adapun hubungan antar variabel berdasarkan kerangka pikir ditentukan model penelitian sebagai berikut:

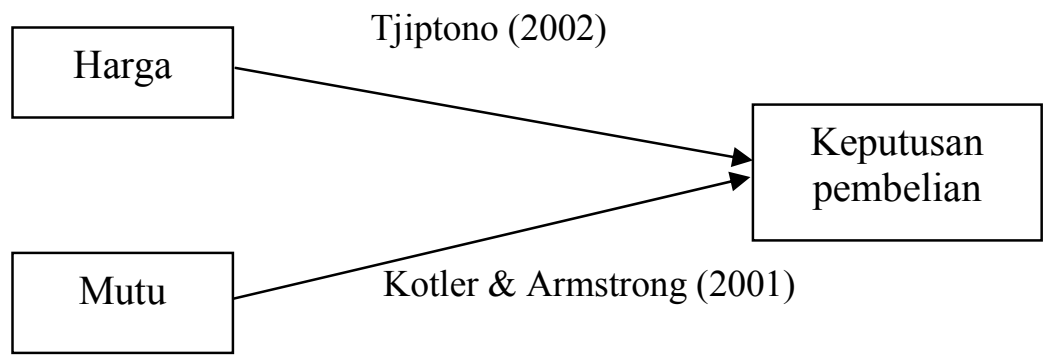

Gambar 5 : Kerangka Konseptual Penelitian

gambar 5 diatas, analisis data dilakukan dengan menganalisis masingmasing sub variabel bebas dengan variabel terikat, kemudian kempat sub variabel dianalisis secara bersama-sama dengan variabel terikat. Dengan demikian penelitian ini menggunakan teknik analisis linier berganda (multiple regression), dimana teknik tersebut akan menguji hipotesis yang menyatakan diduga ada pengaruh sendiri-sendiri dan pengaruh secara bersama-sama diantara variabel bebas terhadap variabel terikat.

\section{Hipotesis}

Hipotesis yang diajukan dalam penelitian ini adalah:

1. Ada pengaruh harga terhadap keputusan pembelian kartu seluler secara parsial.

2. Ada pengaruh mutu terhadap keputusan pembelian kartu seluler secara parsial.

3. Ada pengaruh harga dan mutu secara simultan terhadap keputusan pembelian kartu seluler.

\section{METODE}

\section{Rancangan Penelitian}

Penelitian ini, merupakan jenis penelitian explanatory research guna menjelaskan hubungan kausal antara variabel-variabel melalui pengujian hipotesis. 
explanatory research dalam penelitian ini digunakan untuk menguji hipotesis tentang ada tidaknya pengaruh atribut produk terhadap keputusan pembelian kartu perdana.

\section{Populasi dan Teknik Pengambilan Sampel}

Populasi dalam penelitian ini adalah seluruh Mahasiswa Universitas Kanjuruhan Malang angkatan 2008-2011. Teknik pengambilan sampel dalam penelitian ini menggunakan metode purposive sampling. Kriteria sampel dalam penelitian ini adalah seluruh mahasiswa yang menggunakan kartu selular Telkomsel, Indosat dan XL yang berada di Universitas Kanjuruhan Malang. Penentuan besarnya sampel, peneliti menggunakan teori Roscoe dalam Sugiyono (2006) yang menyatakan bahwa bila dalam suatu penelitian akan melakukan analisis dengan multirative (korelasi atau regresi berganda), maka jumlah anggota sampel minimal 10 kali dari jumlah variabel yang diteliti (independen + dependen). Sedangkan dalam penelitian ini menggunakan 2 variabel independen dan 1 variabel dependen. Maka jumlah sampel minimal yang ditetapkan dalam penelitian ini adalah sebanyak 30 sampel. Berdasarkan atas pertimbangan kepentingan penelitian ini, peneliti perlu menambahkan jumlah sampel. Maka peneliti menambahkan jumlah sampel menjadi 355 sampel, diambil dari teori Sugiyono (2006) sebesar 5\% dari keseluruhan jumlah populasi.

\section{Teknik Pengumpulan Data}

Pengumpulan data dalam penelitian ini dilakukan dengan menggunakan kuesioner (angket). Pengumpulan data dilaksanakan dengan membuat daftar pertanyaan yang diajukan kepada responden untuk memperoleh persepsi responden terhadap variabel harga (X1), mutu (X2) terhadap keputusan pembelian kartu seluler pada Mahasiswa Universitas Kanjuruhan Malang.

\section{Definisi Operasional variabel}

Variabel yang dianalisis dalam penelitian ini dibedakan menjadi variabel bebas (independent) dan variabel terikat (dependent).

1. Variabel bebas (independent) merupakan variabel yang nantinya akan mempengaruhi variabel terikat. Adapun variabel bebas adalah harga (X1), mutu (X2).

2. Variabel terikat (dependents) adalah variabel tergantung yang keberadaannya dipengaruhi variabel bebas. Dalam penelitian ini variabel terikat tersebut adalah Keputusan Pembelian (Y).

Definisi operasional variabel dari masing-masing variabel penelitian ini adalah sebagai berikut:

1. Harga (X1), merupakan alat komunikasi dengan pembeli yang digunakan untuk memposisikan produk dengan produk pesaingnya. Harga dalam penelitian ini merupakan persepsi responden tentang harga kartu selular dikalangan mahasiswa. Indikator harga yang diungkapkan Zeithaml, dalam Irawan (2003) meliputi: 

a. Kewajaran Harga
b. Perkiraan Harga
c. Harga Pengorbanan

2. Mutu (X2), mutu adalah salah satu alat penting bagi pemasar untuk menetapkan posisi. Mutu produk berarti kemampuan produk untuk melaksanakan fungsinya, termasuk didalamnya keawetan, keandalan, ketepatan, kemudahan dipergunakan dan diperbaiki, serta atribut bernilai yang lain (Kotler dan Armstrong, 2003). Adapun indikator-indikator mutu antara lain:
a. Keawetan
b. Keandalan
c. Ketepatan
d. Kemudahan

3. Keputusan Pembelian (Y) merupakan pemilihan dari dua atau lebih pilihan alternatif produk yang akan dibeli. Keputusan dalam penelitian ini merupakan keputusan respponden dalam memilih kartu seluler. Indicator keputusan pembelian dalam penelitian ini Yazid, (2005) meliputi:
a. Kualitas pencarian
b. Kualitas pengalaman
c. Kualitas keyakinan

\section{PEMBAHASAN}

Deskripsi Responden

Responden adalah sampel penelitian yang berjumlah 355 orang mahasiswa/mahasiswi Universitas Kanjuruhan Malang yang masih aktif dan belum lulus yang dimintai kesediaannya untuk memberikan tanggapan ataupun jawaban atas masalah/pertanyaan yang disampaikan. Seluruh responden dipilih secara purposive sampling.

\section{Jenis Kelamin Responden}

Karakteristik responden berdasarkan jenis kelamin dapat dilihat pada tabel berikut:

Tabel 1: Karakteristik responden berdasarkan jenis kelamin

\begin{tabular}{|l|l|l|}
\hline Jenis Kelamin & Jumlah Responden & Prosentase (\%) \\
\hline Laki-Laki & 178 & $60 \%$ \\
\hline Perempuan & 177 & $40 \%$ \\
\hline Jumlah & 355 & $100 \%$ \\
\hline
\end{tabular}

Sumber: Data Primer (diolah), Maret 2012

\section{Program Studi}

Sampel penelitian ini ada 18 program studi dari Universitas Kanjuruhan Malang sejumlah $355 \mathrm{sampel} / \mathrm{responden}$. 
Tabel 2: Karakteristik responden berdasarkan program studi

\begin{tabular}{|l|l|l|l|}
\hline No & Program Studi & $\begin{array}{l}\text { Jumlah } \\
\text { Keseluruhan }\end{array}$ & $\begin{array}{l}\text { Yang } \\
\text { Dijadikan } \\
\text { Sampel }\end{array}$ \\
\hline 1 & Bimbingan \& Konseling & 603 & 30 \\
\hline 2 & Pend. Ekonomi & 373 & 19 \\
\hline 3 & PPKn & 211 & 11 \\
\hline 4 & Pend. Geografi & 479 & 24 \\
\hline 5 & Pend. Matematika & 1024 & 51 \\
\hline 6 & Pend. Fisika & 369 & 18 \\
\hline 7 & Pend. Bahasa \& Sastra Indonesia & 600 & 30 \\
\hline 8 & Pend. Bahasa Inggris & 1266 & 61 \\
\hline 9 & PGSD & 629 & 31 \\
\hline 10 & Sastra Inggris & 85 & 5 \\
\hline 11 & Sastra Jepang & 30 & 2 \\
\hline 12 & Teknik Informatika & 248 & 12 \\
\hline 13 & Manajemen Informatika & 27 & 2 \\
\hline 14 & Sistem Informasi & 469 & 23 \\
\hline 15 & Manajemen & 230 & 12 \\
\hline 16 & Akuntansi & 247 & 13 \\
\hline 17 & Ilmu Hukum & 127 & 6 \\
\hline 18 & Peternakan & 99 & 5 \\
\hline Total & & 355 \\
\hline
\end{tabular}

Sumber: ka. BAA Universitas Kanjuruhan Malang, 2011/2012

Tabel 3: kartu seluler yang digunakan mahasiswa

\begin{tabular}{|l|l|l|l|}
\hline No & Jenis Kartu & Jumlah & $\begin{array}{l}\text { Persentase } \\
(\mathbf{\% )}\end{array}$ \\
\hline 1 & Telkomsel & 98 & $28 \%$ \\
\hline 2 & Indosat & 122 & $34 \%$ \\
\hline 3 & Xl & 135 & $38 \%$ \\
\hline \multicolumn{2}{|l}{ Total } & 355 & $100 \%$ \\
\hline
\end{tabular}

Sumber: data primer (diolah), Maret 2012

\section{Hasil Analisis Regresi Linier Berganda}

Analisis regresi linier berganda digunakan untuk mengetahui seberapa besar pengaruh variabel bebas yaitu harga $\left(\mathrm{X}_{1}\right)$ dan mutu $(\mathrm{X} 2)$ terhadap keputusan pembelian (Y). Hasil analisis terlihat dalam tabel berikut : 
Tabel 4: Ikhtisar Output Regresi Linier Berganda

\begin{tabular}{|c|c|c|c|c|c|}
\hline \multirow{2}{*}{$\begin{array}{l}\text { Variabel } \\
\text { Independen }\end{array}$} & \multicolumn{2}{|c|}{$\begin{array}{l}\text { Unstandardized } \\
\text { Coefficients }\end{array}$} & \multirow[t]{2}{*}{ Beta } & \multirow[t]{2}{*}{ t-hitung } & \multirow[t]{2}{*}{ Sign. $T$} \\
\hline & $B$ & Error & & & \\
\hline (Constant) & 7.556 & 1.446 & & 5.224 & .000 \\
\hline Harga $\left(X_{1}\right)$ & .089 & .044 & .091 & 2.019 & .044 \\
\hline Mutu $\left(\mathrm{X}_{2)}\right.$ & .434 & .036 & .539 & 11.975 & .000 \\
\hline$R$ Square $\left(R^{2}\right)$ & 0.319 & & & & \\
\hline Adusted. R Square & 0.315 & & & & \\
\hline $\mathrm{F}_{\text {-hitung }}$ & $=82.272$ & & & & \\
\hline Sign-F & $=0.000$ & & & & \\
\hline$S E$ & $=2.371$ & & & & \\
\hline Variabel Dependent & \multicolumn{5}{|c|}{$=$ keputusan pembelian } \\
\hline
\end{tabular}

Sumber : Output SPSS, Maret 2012

Dari tabel 4 diatas maka persamaan regresi sebagai berikut:

$\mathrm{Y}=7.556+0,089 \mathrm{X}_{1}+0,434 \mathrm{X}_{2}$

Dari persamaan regresi tersebut, diketahui bahwa:

a. Nilai konstanta sebesar 7.556 apabila dibenak konsumen sama sekali tidak memiliki pemahaman gambaran tentang harga dan mutu. Kalau dianalogikan, tingkat keputusan pembelian akan bernilai 7.556 apabila tidak ada pengaruh sama sekali dari harga dan mutu.

b. Variabel harga $\left(X_{1}\right)$ memiliki nilai positif sebesar 0,089. Hal ini menyatakan bahwa setiap satuan variabel harga akan memberi pengaruh sebesar 0,089 terhadap keputusan pembelian apabila variabel lainnya tetap. Data tersebut menunjukkan bahwa harga berpengaruh positif (searah) terhadap keputusan pembelian, artinya semakin terjangkau harga kartu seluler disertai fasilitas yang baik maka akan semakin tinggi pula tingkat keputusan pembelian konsumen.

c. Variabel mutu $\left(\mathrm{X}_{2}\right)$ memiliki nilai positif sebesar 0,434. Hal ini menyatakan bahwa setiap satuan variabel mutu akan memberi pengaruh sebesar 0,434 terhadap keputusan pembelian apabila variabel lainnya tetap. Data tersebut menunjukkan bahwa mutu berpengaruh positif (searah) terhadap keputusan pembelian, artinya semakin tinggi atau semakin baik mutu kartu seluler maka ssemakin tinggi pula minat konsumen untuk melakukan keputusan pembelian kartu seluler tersebut.

\section{Uji F (Uji model)}

Uji F/uji model digunakan untuk membuktikan apakah model regresi linier berganda di atas dengan menggunakan 2 variabel yaitu harga dan mutu cukup mampu mempengaruhi keputusan pembelian.

Dari tabel 4 diatas, terlihat nilai $F$ hitung sebesar 82.272 dengan signifikan sebesar 0,000, berarti Signifikan F lebih kecil dari 0,05 menunjukan bahwa semua 
variabel harga $\left(\mathrm{X}_{1}\right)$ dan mutu $\left(\mathrm{X}_{2}\right)$ secara bersama-sama mampu mempengaruhi variabel keputusan pembelian $(\mathrm{Y})$.

\section{Uji Hipotesis}

Pada bagian ini dilakukan analisis data untuk menguji hipotesis $1 \mathrm{~s} / \mathrm{d} 2$ dan uji hipotesis 3 menggunakan nilai standardized beta.

\section{Uji Hipotesis 1 s/d 2}

Untuk melihat pengaruh dari variabel harga dan mutu digunakan uji-t, dan dari hasil analisis pada tabel 4 di atas terlihat bahwa:

a. Variabel harga $\left(\mathrm{X}_{1}\right)$ menunjukan nilai signifikan t sebesar $0,044<0,05$, berarti ada pengaruh yang signifikan dari variabel harga terhadap variabel keputusan pembelian (Y). Dengan demikian dapat disimpulkan bahwa hipotesis 1 diterima.

b. Variabel mutu $\left(\mathrm{X}_{2}\right)$ menunjukan nilai signifikan t sebesar $0,000<0,05$, berarti ada pengaruh yang signifikan dari variabel mutu terhadap variabel keputusan pembelian (Y).

Dari penjabaran diatas menunjukan bahwa variabel harga dan mutu mempunyai pengaruh yang signifikan terhadap keputusan pembelian, karena memiliki nilai signifikan $\mathrm{t}<0,05$.

\section{Uji Hipotesis Ke-3}

Hipotesis ke 3 menyebutkan bahwa variabel harga $\left(\mathrm{X}_{1}\right)$ dan variabel mutu $\left(\mathrm{X}_{2}\right)$ secara bersama-sama mampu mempengaruhi terhadap keputusan pembelian.

Berdasarkan pengujian dengan t-test kedua variabel berpengaruh signifikan terhadap keputusan pembelian (Y). Hasil perhitungan menunjukan bahwa nilai standardized beta variabel harga $\left(\mathrm{X}_{1}\right)$ sebesar 0,044 , sedangkan pada variabel mutu $\left(\mathrm{X}_{2}\right)$ sebesar 0,000. Dan nilai standardized beta kedua variabel tersebut $<0,05$ maka keduanya mampu mempengaruhi keputusan pembelian.

Atas dasar pengertian di atas, maka hipotesis yang berbunyi variabel harga dan variabel mutu secara bersama-sama memiliki pengaruh terhadap keputusan pembelian, dengan demikian hipotesis ke 3 dapat diterima atau teruji kebenarannya.

\section{Pembahasan Hipotesis I (Indikator Harga)}

Dari deskripsi data dan analisis hasil penelitian tentang variabel harga yang telah dijelaskan pada bab sebelumnya dapat dinyatakan bahwa harga memang mampu mempengaruhi konsumen dalam melakukan keputusan pembelian kartu seluler dan harga pulsa kartu seluler yang paling dipertimbangkan oleh konsumen ketika akan membeli kartu seluler. Dari indikator perkiraan harga konsumen juga mempertimbangkan harga pulsa kartu seluler, dan biaya transportasi ketika ingin membeli juga menjadi pertimbangan konsumen ketika akan membeli kartu seluler.

Kotler (2003) menyatakan bahwa harga adalah sejumlah barang yang bisa ditawarkan ke pasar untuk mendapatkan perhatian, dibeli dan dipergunakan atau dikonsumsi dan yang dapat memuaskan keinginan atau kebutuhan konsumen. Berdasarkan pendapat Kotler tersebut, bisa diketahui bahwa produk suatu barang, jasa, organisasi, instansi atau hal lainnya akan bisa terbentuk di benak seseorang dengan cara melibatkan diri dengan sesuatu/benda tersebut, baik itu dengan 
melihat, mendengar, meraba, merasakan atau bahkan hanya dengan memikirkannya. Sama halnya dengan penelitian ini, produk kartu seluler telkomsel yang di produksi oleh PT. Telkomsel Tbk, indosat produk dari PT. Indosat Tbk dan xl dari PT. Excelkomindo Tbk, akan bisa terbentuk dibenak konsumen apabila konsumen bisa mengetahui dan pernah menggunakan produk dari salah satu perusahaan provider tersebut.

Penelitian ini mengambil sampel dari konsumen yang sudah menggunakan kartu seluler telkomsel, indosat atau xl sehingga diharapkan hasil penelitiannya benar-benar sesuai persepsi yang telah terbentuk dibenak konsumen mengenai produk dari kartu seluler.

Berdasarkan hasil analisis linier berganda dapat diketahui bahwa harga memang mempunyai pengaruh terhadap keputusan konsumen dalam melakukan pembelian kartu seluler baik telkomsel, indosat maupun xl, dan pengaruh yang muncul dari harga bernilai signifikan dan hal itu ditunjukkan oleh hasil uji t. Bagi responden, ketika mereka ingin melakukan pembelian kartu seluler memang harga menjadi pertimbangan mereka sebelum melakukan pembelian, dan mereka menganggap bahwa dengan harga yang terjangkau mereka bisa mendapatkan apa yang telah menjadi harapan mereka.

Konsumen (mahasiswa) Universitas Kanjuruhan Malang paling banyak menggunakan kartu $\mathrm{xl}$ dengan besar nilai prosentase 38\%, dan dari hasil analisis dapat diketahui harga pulsa yang wajar dan harga produk kartu seluler memiliki nilai rata-rata mendekati 4 (setuju) yakni sebesar 4,38 dan 4,12. Ini membuktikan bahwa harga pulsa yang wajar dan harga kartu seluler memiliki tingkat pengaruh yang sangat besar terhadap keputusan konsumen dalam keputusan pembelian. Sedangkan petimbangan lain konsumen tentang perkiraan harga pulsa Telkomsel, Indosat dan Xl sesuai dengan harapan memiliki nilai sebesar 4,01 serta perkiraan harga dengan kualitas yang didapatkan memiliki nilai sebesar 3,93 dan konsumen mempertimbangkan biaya transportasi dan biaya komunikasi ketika akan membeli kartu seluler dengan memiliki nilai rata-rata 3,65 dan 3,61. Dapat disimpulkan bahwa konsumen tidak hanya asal pilih terhadap produk kartu seluler yang di gunakan seperti halnya biaya transportasi dan biaya komunikasi juga dipertimbangkan dalam keputusan pembelian.

Hasil penelitian ini sesuai dengan teori dari Tjiptono (2002) bahwa harga digunakan untuk memposisikan merek suatu produk sebagai merek bermutu atau sebaliknya, dan harga merupakan dasar perbandingan diantara merek-merek pesaing lainnya. Dari sini dapat dilihat bahwa xl mampu membuktikan bahwa dengan memainkan harga yang terjangkau bagi semua kalangan serta dari harga yang terjangkau tersebut konsumen mendapatkan apa yang diharapkan dan mampu bersaing dengan kartu seluler lain yang sejenis.

Akan tetapi hasil penelitian ini memiliki perbedaan dengan penelitian yang dilakukan oleh Puspita (2007) yang berjudul analisis pengaruh atribut produk terhadap Keputusan pembelian Kebab Turki Baba Rafi di Yogyakarta. dimana harga memiliki pengaruh sedang terhadap keputusan pembelian konsumen. Peran harga dalam penentuan keputusan pembelian sudah menjadi faktor utama konsumen. Persepsi harga yang terjangkau di benak konsumen akan menjadi dorongan bagi mereka untuk melakukan pembelian dan konsumen akan setia terhadap produk tersebut. 
Kartu seluler yang di gunakan adalah Telkomsel, Indosat dan Xl yang mana dari masing-masing kartu seluler memiliki keunggulan-keunggulan yang bisa menjadi daya tarik bagi konsumen yang akan membeli kartu seluler, diantaranya dari telkomsel memiliki fasilitas dengan jangkauan terluas, indosat dengan bonus sms, telepon serta internet dan memiliki berbagai paket yang di tawarkan. Sedangkan xl memiliki fasilitas paket telepon, sms dan internet murah serta bisa membuat grup dengan tariff telepon yang murah.

Dari hasil uji t bisa disimpulkan bahwa hipotesis I diterima karena variabel harga $\left(\mathrm{X}_{1}\right)$ berpengaruh signifikan terhadap keputusan pembelian konsumen $(\mathrm{Y})$.

\section{Pembahasan Hipotesis II (Indikator Mutu)}

Hasil analisis linier berganda pada bab IV menjelaskan bahwa terjadi pengaruh yang signifikan dari variabel mutu terhadap keputusan pembelian. Baik di uji secara bersama-sama maupun secara parsial dan hipotesis II diterima karena variabel mutu signifikan dan berpengaruh terhadap keputusan pembelian konsumen (Y).

Hasil analisis statistik juga menjelaskan bahwa keandalan jangkauan/jaringan dan tersedianya kartu seluler dimana-mana menjadi pertimbangan bagi konsumen ketika akan membeli kartu Telkomsel, Indosat dan $\mathrm{X} 1$.

Berdasarkan statistik, responden selalu memperhatikan keandalan kartu seluler dan keandalan jaringan atau jangkauan kartu seluler dalam membeli kartu seluler dengan nilai rata-rata sebesar 4,35 dan 4,37. Konsumen sangat memperhatikan keandalan kartu seluler dan keandalan dari jangkauan atau jaringan kartu seluler yang digunakan, jika di rasa jaringan atau keandalan kartu kurang bagus maka konsumen tidak akan memilih kartu seluler Telkomsel, Indosat dan Xl, keandalan kartu seluler dan jaringan sanagt mempengaruhi konsumen dalam keputusan pembelian. Ketepatan dalam pengiriman pesan serta ketepatan jaringan juga menjadi pertimbangan konsumen dalam membeli kartu seluler (masingmasing 4,25 dari distribusi frekuensi jawaban responden). Ketepatan dalam pengiriman pesan serta ketepatan jaringan juga mempengaruhi konsumen, karena jika sering terjadi gangguan maka konsumen akan enggan untuk memilih kartu seluler Telkomsel, Indosat dan Xl. Responden selalu memperhatikan keberadaan kartu seluler yang ada di mana-mana sehingga dapat dengan mudah diperoleh serta letak counter yang berada dimana-mana dari kartu seluler Telkomsel, Indosat dan $\mathrm{Xl}$ (4,37 dan 4,34 dari distribusi frekuensi jawaban responden). Sedangkan keawetan kartu seluler dan sering melakukan ganti kartu sebesar 4,23 dan 3,87. Hal ini berarti bahwa konsumen memperhatikan keawetan kartu seluler yang mereka gunakan agar mereka tidak melakukan penggantian kartu sesering mungkin dalam beberapa periode tertentu.

Dari hasil statistik dapat dilihat bahwa konsumen lebih memperhatikan keandalan jangkauan dan tersedianya kartu seluler dimana-mana sehingga mudah untuk didapatkan oleh konsumen. Konsumen juga menggati kartu mereka ketika mereka tidak mendapatkan apa yang mereka harapkan dari kartu yang mereka gunakan, maka dari itu konsumen sangat memperhatikan keawetan kartu seluler yang mereka gunakan. Hal ini berarti bahwa persepsi tentang mutu yang ada dibenak konsumen bersifat kuat dan berpengaruh secara signifikan. 
Kondisi ini menggambarkan bahwa konsumen/responden pada penelitian ini menjadikan mutu sebagai dasar pertimbangan pengambilan keputusan pembelian. Hal ini dikarenakan bahwa memang mutu dari kartu seluler sangat di pertimbangkan oleh konsumen dalam menentukan keputusan pembelian. Sesuai dengan teori dari Kotler dan Armstrong (2003) ynag mengatakan bahwa mutu produk berarti kemampuan produk untuk melaksanakan fungsinya, termasuk didalamnya keawetan, keandalan, ketepatan, kemudahan dipergunakan dan diperbaiki. Konsumen berharap bahwa dengan mutu yang baik konsumen akan setia dan tidak mengganti-ganti kartu yang telah digunakan. Penelitian ini menghasilkan temuan bahwa mahasiswa (responden) mempertimbangkan keandalan dari produk yang akan dibeli. Penelitian ini mendukung dari penelitian sebelumnya yang di lakukan oleh Supriyanto (2009) yang mana mutu mempunyai pengaruh yang signifikan terhadap keputusan pembelian.

\section{Pembahasan Hipotesis III atribut produk harga $\left(X_{1}\right)$ dan mutu $\left(X_{2}\right)$ memiliki pengaruh terhadap keputusan pembelian (Y)}

Hipotesis ke III ini melihat besarnya nilai $t$ test dari masing-masing variabel. Pada penelitian ini menggunakan dua variabel bebas yaitu harga $\left(\mathrm{X}_{1}\right)$ dan mutu $\left(\mathrm{X}_{2}\right)$ dari kedua variabel bebas tersebut masing-masing memiliki nilai $t$ test sebesar: harga $\left(\mathrm{X}_{1}\right)$ sebesar 0,044 , sedangkan pada variabel mutu $\left(\mathrm{X}_{2}\right)$ sebesar 0,000 , dan hasil penelitian ini menyebutkan bahwa harga dan mutu secara bersama-sama mempengaruhi keputusan pembelian karena $<0,05$.

Berdasarkan hasil di atas maka dapat disimpulkan bahwa hipotesis ke III diterima karena harga dan mutu mampu mempengaruhi keputusan pembelian.

Peneliti menyimpulkan bahwa memang harga dan mutu diperhatikan dalam keputusan pembelian konsumen, terutama jika harga terjangkau dan memiliki kualitas yang baik yang mampu mengena di hati konsumen, dan untuk produk kartu seluler seperti ini perusahaan harus kreatif dalam menciptakan ide-ide dengan menambahkan fasilitas atau bonus yang bisa membuat konsumen tetap setia terhadap produk yang telah digunakan.

\section{KESIMPULAN}

1. Harga mempunyai pengaruh terhadap keputusan konsumen dalam melakukan pembelian kartu seluler baik telkomsel, indosat maupun xl, dan pengaruh yang muncul dari harga bernilai signifikan

2. Persepsi tentang mutu yang ada dibenak konsumen bersifat kuat dan berpengaruh secara signifikan. Sehingga mutu mempunyai pengaruh yang signifikan terhadap keputusan pembelian.

3. Harga dan mutu secara bersama-sama mempengaruhi keputusan pembelian

\section{DAFTAR PUSTAKA}

Arikunto, Suharsini, 2002, Prosedur Penelitian: Suatu Pendekatan Praktik, Edisi Revisi VI, Cetakan Ketigabelas, Penerbit Rineka Cipta, Jakarta. 
Gitosudarmo, Indriyo, 2000, Strategi Pemasaran, Andi offset, Yogyakarta.

Ghozali, Imam, 2005, Aplikasi Analisis Multirative dengan Program SPSS, Badan Penerbit Universitas Diponegoro Semarang, Semarang.

Irawan, Handi, 2003, Manajemen Pemasaran, Bandung.

Kerlinger, Fred, 2004, Asas-Asas Penelitian Behavioral, Gajahmada University Press, Yogyakarta.

Kotler, Philip, 2008, Manajemen Pemasan, PT INDEKS, Jakarta.

Kotler, Philip, 2005, Manajemen Pemasaran, Jilid I, Edisi Kesebelas, PT. Indeks kelompok Gramedia, Jakarta.

Kotler, Philip \& Amstrong, G, 2003, Prinsip-Prinsip Pemasaran, Diterjemahkan oleh: Wilhelminus W. Bakowaston, Erlangga, Jakarta.

Kotler, Philip \& Amstrong, G, 2001, Prinsip-Prinsip Pemasaran, Jilid I, Edisi kedelapan, Erlangga, Jakarta.

Kotler, Philip \& Keller, Kevin Lane, 2008, Manajemen Pemasaran, Jilid I, Edisi Keduabelas, PT INDEKS, Jakarta.

Pamujo, Nivian Yuga, 2011, Analisis Pengaruh Atribut Produk, Bauran Promosi, Dan Kualitas Pelayanan Terhadap Keputusan Pembelian Produk Merchandise, Skipsi, Fakultas Ekonomi Universitas Diponegoro Semarang.

Puspita, Bayu, 2007, Analisis Pengaruh Atribut Produk Terhadap Keputusan Pembelian Kebab Turki Baba Rafi Di Yogyakarta, Skripsi, Fakultas Ekonomi Universitas Islam Indonesia Yogyakarta.

Schiffman \& Kanuk, 2004, Perilaku Konsumen, Edisi Ketujuh, Prentice hall, Jakarta.

Sugiyono, 2004, Metode Penelitian untuk Bisnis, Cetakan Kedelapan, CV. Alfabeta, Bandung.

Sugiyono, 2006, Metode Penelitian Pendidikan (Pendekatan Kuantitatif, kualitatif dan $R \& D)$. Bandung : Alfabeta.

Sukardi, 2004, Metodologi Penelitian Pendidikan Kompetensi dan Prakteknya, Cetakan Kedua, PT. Bumi Aksara, Jakarta.

Sumarwan, Ujang, 2003, Perilaku Konsumen Teori dan Penerapannya dalam Pemasaran, Ghalia Indonesia, Bogor.

Supriyanto, Agus, 2009, Pengaruh Atribut Produk Terhadap Keputusan Pembelian pada Mahasiswa Pengguna Handphone Nokia di Universitas Kanjuruhan Malang, Skripsi, Fakultas Ekonomi Universitas Kanjuruhan Malang.

Swasta, Basu \& T. Hani Handoko, 2000, Manajemen Pemasaran Analisa Perilaku Konsumen, BPFE, Yogyakarta.

Tjiptono, Fandy, 2001, Strategi Pemasaran, Andi Offset, Yogyakarta. ,2002, Strategi Pemasaran, Andi Offset, Yogyakarta. 
Fitrianingrum dan Tries Edy W, Pengaruh Harga dan Mutu... 139 , 2008, Strategi Pemasaran, Andi Offset, Yogyakarta.

Yazid, 2005, Pemasaran Jasa: Konsep dan Implementasi, Penerbit Ekonosia, Yogyakarta.

www.arbaky.blogspot.com. Di akses 26 November 2011. www.Operatorseluler.com. Di akses 26 November 2011. www.Republika.co.id. Diakses 26 November 2011. 